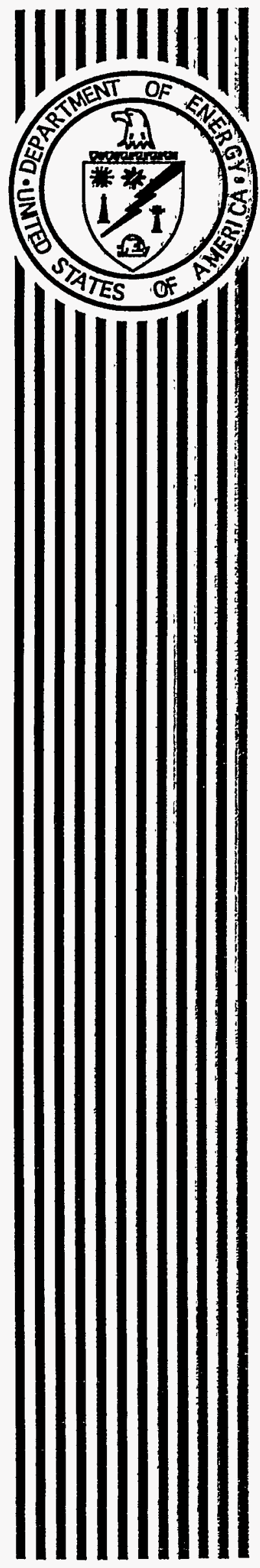

DOE/EA-0990

\title{
Environmental Assessment for the \\ Offsite Commercial Cleaning of \\ Controlled and Routine Laundry from the Savannah River Site
}

\section{DECEMBER 1994}

\section{U. S. DEPARTMENT OF ENERGY SAVANNAH RIVER OPERATIONS OFFICE SAVANNAH RIVER SITE}




\section{DISCLAIMER}

This report was prepared as an account of work sponsored by an agency of the United States Government. Neither the United States Government nor any agency thereof, nor any of their employees, make any warranty, express or implied, or assumes any legal liability or responsibility for the accuracy, completeness, or usefuiness of any information, apparatus, product, or process disclosed, or represents that its use would not infringe privately owned rights. Reference herein to any specific commercial product, process, or service by trade name, trademark, manufacturer, or otherwise does not necessarily constitute or imply its endorsement, recommendation, or favoring by the United States Government or any agency thereof. The views and opinions of authors expressed herein do not necessarily state or reflect those of the United States Government or any agency thereof. 


\section{DISCLAIMER}

Portions of this document may be illegible in electronic image products. Images are produced from the best available original document. 


\title{
Finding of No Significant Impact \\ For the \\ Offsite Commercial Cleaning of \\ Controlled and Routine Laundry \\ from the Savannah River Site
}

Agency: U. S. Department of Energy

Action: Finding of No Significant Impact

Summary: The U.S. Department of Energy (DOE) has prepared an Environmental Assessment (EA) (DOE/EA-0990) on the offsite commercial cleaning of controlled and routine laundry from the Savannah River Site (SRS) near Aiken, South Carolina. Based on analyses in the EA of impacts associated with the onsite and offsite components of vendor cleaning of Site laundry, DOE has determined the proposed action is not a major Federal action significantly affecting the quality of the human environment, within the meaning of the National Environmental Policy Act (NEPA) of 1969. Therefore, preparation of an environmental impact statement is not required and DOE is issuing this Finding of No Significant Impact (FONSI).

\section{Public Availability:}

Copies of the EA and FONSI or further information on the DOE NEPA process are available from:

\author{
Mr. A. Ben Gould \\ Director, Environmental Compliance Division \\ U.S. Department of Energy \\ Savannah River Operations Office \\ P.O. Box A \\ Aiken, South Carolina 29802 \\ Phone: (803) 725-5967 \\ FAX: (803) 725-7688
}

Background: SRS operational activities require personnel to wear some level of protective clothing for radiological and environmental work areas. Such levels can range from minimum (e.g., a laboratory coat) to maximum (e.g., full protective clothing including respirator) degrees of protection. Once the clothing has been worn or used, it must be cleaned and monitored prior to being reissued for use by Site personnel. Approximately 1.1 to 1.5 million kilograms ( 2.5 to 3.5 million pounds) of controlled and routine protective clothing and 90,000 to 100,000 respirator units are processed for cleaning annually at the SRS. Items of protective clothing and respirators are currently processed in subcontracted operations at existing SRS facilities. The existing Site laundry, constructed in 1953, is presently operating on a single-shift basis. This facility is currently faced with a number of environmental compliance concerns. The DOE needs to take action to provide SRS workers with an uninterrupted supply of clean protective clothing and clean and functional respirators for use in the performance of SRS operations. The purpose of the proposed action is to provide SRS with a cost-effective means of meeting site demands for clean protective clothing and respirators.

Proposed Action: The proposed action is to establish a coordinated effort by both SRS programs and a contracted vendor to provide offsite services for commercial cleaning of controlled and routine laundry generated onsite. Controlled laundry consists of protective

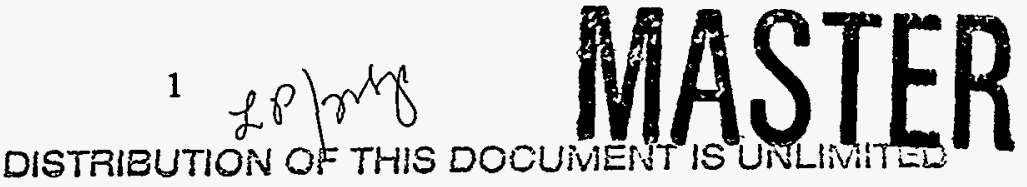


clothing and respirator equipment potentially containing radioactive contamination resulting from activities at SRS facilities. Routine laundry includes uncontaminated protective clothing. In general, the proposed action would require three separate stages including: (1) collection onsite prior to shipment to vendor facility; (2) laundering by the vendor at the offsite facility (including delivery to and from the offsite facility); and (3) distribution onsite after laundering.

The collection process onsite prior to shipment to the vendor facility would entail pickup, monitoring, and packaging of dirty laundry. The following SRS areas would be involved in the proposed action: A, C, D, E, F, H, K, L, M, N, P, S, Z, and T. Additional steps to the current onsite process would be required to prepare the dirty laundry for offsite shipment to ensure items sent offsite meet appropriate Health Protection and Department of Transportation contamination limits. New onsite facilities associated with the proposed action would include the dirty staging area (process-out facility) and the Protective Clothing distribution center (process-in facility). The currently proposed and combined onsite location of these facilities would be the existing laundry facility. The processing onsite after laundering would entail random monitoring prior to distribution of the cleaned laundry for reuse.

The vendor processing associated with this proposed action would include capabilities to perform delivery of packaged dirty laundry to the offsite facility in accordance with Department of Transportation shipping requirements, full and complete laundering services, and return of packaged cleaned laundry to the Site. Laundering services at the vendor facility would encompass decontaminating, cleaning, disinfecting, drying, monitoring, sorting, folding, simple and reasonable repairs, and boxing/packaging of both controlled and routine SRS laundry. Discardable material would be packaged and returned to SRS. The normal cleaning turn-around time required of the vendor would be 48 hours. An emergency turn-around time of 24 hours would also be implemented as necessary.

Under terms of the contract, the vendor would be responsible for identifying and complying with all applicable laws and regulations governing operation of the offsite facility and shipment of laundry to and from SRS. This would further include having capabilities to obtain all applicable State and Federal licenses and permits necessary to provide and operate a nuclear laundry facility at the vendor's location. The vendor would also be required to have capabilities to obtain necessary licenses and permits to handle and dispose of various radioactive or hazardous waste materials which may be potentially generated at the offsite facility. Finally, the vendor would be required to adhere to all SRS safety rules and regulations while operating on Site.

Alternatives: In addition to the proposed action to implement offsite commercial cleaning of controlled and routine SRS laundry, DOE considered the following alternatives: (1) no action/continue to use the existing laundry facility at SRS; (2) expand and refurbish the existing laundry facility at SRS; and, (3) construct a new replacement laundry facility at SRS. None of these alternatives offered all of the distinct advantages of the selected alternative nor were selected due to: (1) failure to ensure compliance with Federal regulations; (2) continuing to require extensive maintenance under an ongoing workload; (3) lack of space for expansion; and (4) more than twice the cost.

Environmental: The potential consequences of offsite vendor cleaning of SRS controlled and routine laundry were analyzed to determine if there were any significant environmental impacts associated with the proposed action. The operation of the vendor facility was assumed to be similar to that of the existing Site laundry for evaluation purposes. Potential impacts were assessed for three primary subject areas including: (1) vendor facility operations; (2) SRS facility operations; and (3) transportation impacts. The

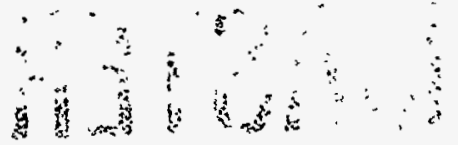


negative environmental consequences were negligible for all three subject areas. Operation of the vendor facility would be similar to the existing Site laundry which is classified as a low hazard facility. A low hazard classification is used to define facilities which, in the event of an unmitigated release of the total radiological inventory contained in that facility, would present only minor onsite and negligible offsite impacts to either people or the environment. Volume of laundry at the dirty staging area would be less than for the existing laundry operation. Therefore, any potential impacts at the dirty staging area would also be less than for existing Site laundry operations. The Site workforce would be decreased less than one percent by switching to the use of an offsite vendor operation. No latent cancer or accident-related fatalities would be expected to result from the proposed action.

Determination: Based on information and analyses in the EA, DOE has determined the proposed offsite commercial cleaning of controlled and routine laundry from the SRS does not constitute a major Federal action significantly affecting the quality of the human environment within the meaning of NEPA. Therefore, an environmental impact statement is not required and DOE is issuing this Finding of No Significant Impact.

Signed in Aiken, South Carolina, this 2 nd day of Aecemles, 1994.

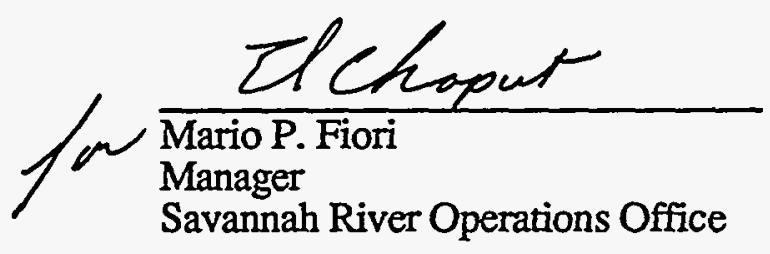


ENVIRONMENTAL ASSESSMENT

for the

\section{OFFSITE COMMERCIAL CLEANING \\ of \\ CONTROLLED AND ROUTINE LAUNDRY \\ from the \\ SAVANNAH RIVER SITE}

U. S. DEPARTMENT OF ENERGY

SAVANNAH RIVER OPERATIONS OFFICE

SAVANNAH RIVER SITE

DECEMBER 1994 
TABLE OF CONTENTS

SECTION

PAGE

1.0 INTRODUCTION AND NEED FOR ACTION 1

$1.1 \quad$ Background

1.2 Purpose and Need for Action

2.0 PROPOSED ACTION AND ALTERNATIVES 2

$2.1 \quad$ Proposed Action

2.2 Alternatives to the Proposed Action

2

2.2.1 No Action, Continue to Use the Existing Laundry Facility at SRS

2.2.2 Expand and Refurbish the Existing Laundry Facility at SRS 8

2.2.3 Construct a New Replacement Laundry Facility at SRS

1

1

1

2

8

8

3.0 ENVIRONMENTAL CONSEQUENCES OF THE PROPOSED ACTION AND ALTERNATIVES

8

3.1 Vendor Facility Operation 8

3.2 SRS Facility Operations 9

3.3 Transportation Impacts 9

3.3.1 Analyzed Scenario 9

3.3.2 Assumptions 10

3.3.3 Consequences 11

3.4 Environmental Consequecnes of the Alternatives 13

3.5 Other Impacts 13

3.5.1 Safeguards and Security 13

3.5.2 Emergency Planning 13

3.6 Cumulative Impacts 13

4.0 REGULATORY AND PERMTTTING PROVISIONS
CONSIDERED

4.1 National Environmental Policy Act of 1969, as

$\begin{array}{lll}4.2 & \text { amended (42 USC 4321 et seq.) } & 15 \\ \text { Air Emission Regulations } & 15\end{array}$

4.3 Liquid Discharge Regulations 15

5.0 AGENCIES AND PERSONS CONSULTED

$\begin{array}{lll}6.0 & \text { REFERENCES } & 16\end{array}$ 


\section{LIST OF TABLES}

TABLE

PAGE

2-1 Listing of maximum contamination limits for transportation and reuse of laundered goods at the Savannah River Site.

3-1 Listing of offsite radiological transportation accident consequences and probabilities associated with the proposed action.

3-2 Nonradiological accident consequences associated with the proposed action.

\section{LIST OF FIGURES}

FIGURE

PAGE

2-1 Flowchart for the commercial cleaning of protective clothing, towels, and buffer pads from Savannah River Site, South Carolina.

2-2 Flowchart for the commercial cleaning of respirators from Savannah River Site, South Carolina.

2-3 Map illustrating the general locations of the various site areas participating in the commercial laundry services at the Savannah River Site, South Carolina. 


\subsection{INTRODUCTION AND NEED FOR ACTION}

This Environmental Assessment (EA) has been prepared by the U. S. Department of Energy (DOE) to assess the potential environmental impacts associated with the offsite commercial cleaning of controlled and routine laundry from the Savannah River Site (SRS) near Aiken, South Carolina. Controlled laundry consists of protective clothing and respirator equipment potentially containing radioactive contamination resulting from activities at SRS facilities. Routine laundry includes uncontaminated protective clothing. The aging onsite SRS laundry facility does not comply with current low hazard nuclear facility standards in DOE Order 6430.1. Constructing a new facility on site or upgrading the existing facility have prohibitive costs. The option to seek a commercial offsite vendor was selected as a viable alternative.

\subsection{Background}

SRS operational activities require personnel to wear some level of protective clothing for radiological and environmental work areas. Such levels can range from minimum (e.g., a laboratory coat) to maximum (e.g., full protective clothing including respirator) degrees of protection. Once the clothing has been worn or used, it must be cleaned and monitored prior to being reissued for use by site personnel. Specific articles of protective clothing used on site include the following: coveralls; lab coats; rubber shoes; cloth boots; rubber gloves; hoods; skull-caps; and respirator units.

Approximately 1.1 to 1.5 million kilograms (2.5 to 3.5 million pounds) of controlled and routine protective clothing and 90,000 to 100,000 respirator units are processed for cleaning annually at the SRS. From 1991 through 1993, the typical distribution between controlled and routine laundry has been 77 (i.e., alpha - 61 percent; beta-gamma - 16 percent) and 23 percent, respectively. Items of protective clothing are currently processed in a subcontracted operation at Building $723-F$, the existing laundry facility located in $F$ Area. This onsite operation provides all services including pickup of dirty laundry, washing, drying, monitoring, packaging, and clean deliveries. The respirators are currently processed under two separate subcontracts. The first subcontract provides dirty pickup, washing, sanitizing, and drying at the 723-F laundry facility. The second subcontract currently requires that subcontract personnel from Building 221-25F come to 723-F to inspect, survey, and disc smear the units for contamination. Following this processing, the laundered respirator units which are free of contamination are taken to 221$25 \mathrm{~F}$ for final inspection, repair, testing, assembly, certification, and packaging prior to release for reuse.

\subsection{Purpose and Need for Action}

The existing SRS laundry facility, constructed in 1953, is presently operating on a twoshift basis. The existing facility is faced with several environmental compliance concerns stemming from a changing regulatory climate [e.g., wastewater impacts to site treatment facilities; no physical separation of controlled and routine processes; lint collector exhausts not equipped with High Efficiency Particulate Air (HEPA) filtration systems]. When wastewater discharge from the existing laundry is diverted to the Effluent Treatment Facility (ETF) in H Area, the surfactants in laundry detergents interfere with the ETF process which removes radioactive materials from the effluent. This results in the effluent not meeting current regulatory requirements under Section 401 of the Clean Water Act. The existing facility requires extensive maintenance under an ongoing workload. DOE needs to take action to provide SRS site workers with an uninterrupted supply of clean protective clothing and clean and functional respirators for use in the performance of SRS 
operations. The purpose of the proposed action is to provide SRS with a cost-effective means of meeting site demands for clean protective clothing, towels, and respirators.

\subsection{PROPOSED ACTION AND ALTERNATIVES}

\subsection{Proposed Action}

The proposed action is to establish a coordinated effort by both SRS site programs and a contracted vendor to provide offsite services for the commercial cleaning of the controlled and routine laundry generated on site. In general, the proposed action would require three separate stages including: (1) collection on site prior to shipment to vendor facility; (2) laundering by the vendor at the offsite facility (including delivery to and from the offsite facility); and (3) distribution on site after laundering. Specific process flowcharts for protective clothing and respirators are presented in Figures 2-1 and 2-2, respectively.

The collection process on site prior to shipment to the vendor facility would entail pickup, monitoring, and packaging of dirty laundry. The following SRS areas would be involved in the proposed action: $A, C, D, E, F, H, K, L, M, N, P, S, Z$, and T (Figure 2-3). Additional steps to the current onsite process would be required to prepare the dirty laundry for offsite shipment to ensure items sent off site meet appropriate Health Protection (HP) and Department of Transportation (DOT) contamination limits (Table 2-1). Site HP would conduct a random check on out-going shipments, with a portion of the bags being opened and the clothing and respirators monitored prior to leaving SRS. Site personnel who monitor protective clothing would be equipped with beta-gamma dose rate (i.e., ion chamber) instruments as well as beta-gamma (i.e., Pancake Geiger-Mueller) and alpha (i.e., ZnS scintillator/photomultiplier) contamination detectors. To monitor personal exposure to ionizing radiation, these workers would also wear both thermoluminescent and self-reading dosimeters

New onsite facilities associated with the proposed action would include the dirty staging area (process-out facility) and the Protective Clothing (PC) distribution center (process-in facility). The currently proposed and combined onsite location of these facilities would be the existing laundry facility. The Building 723-F HEPA filtered exhaust system, currently used in the processing of contaminated respirators, would be utilized to control radioactivity during the inspection of protected clothing by HP prior to release to the vendor. A large exhaust hood with air sampling capability would be added to that system to allow contents of bags to be emptied, sorted, checked and rebagged under controlled conditions.

The vendor collection process associated with this proposed action would include capabilities to perform delivery of the packaged dirty laundry to the offsite facility in accordance with DOT shipping requirements, full and complete laundering services, and return of packaged cleaned laundry to the site. Laundering services at the vendor facility would encompass decontaminating, cleaning, disinfecting, drying, monitoring, sorting, folding, simple and reasonable repairs, and boxing/packaging of both controlled and routine SRS laundry. Discardable material would be packaged and returned to the SRS. Examples of such materials would include: clothing, clothing bags and respirators which exceed the contaminations limits (Table 2-1); any routine laundry intermingled in the same bag with controlled laundry; non-repairable clothing, clothing bags and respirators; lint; and miscellaneous items found in the clothing and respirators (e.g., hard hats, badges, tools, keys, glasses, pens, paper, pencils, nuts, bolts, or other hardware items). The normal cleaning turn-around time required of the vendor would be 48 hours. An emergency turnaround time of 24 hours would also be implemented as necessary. 


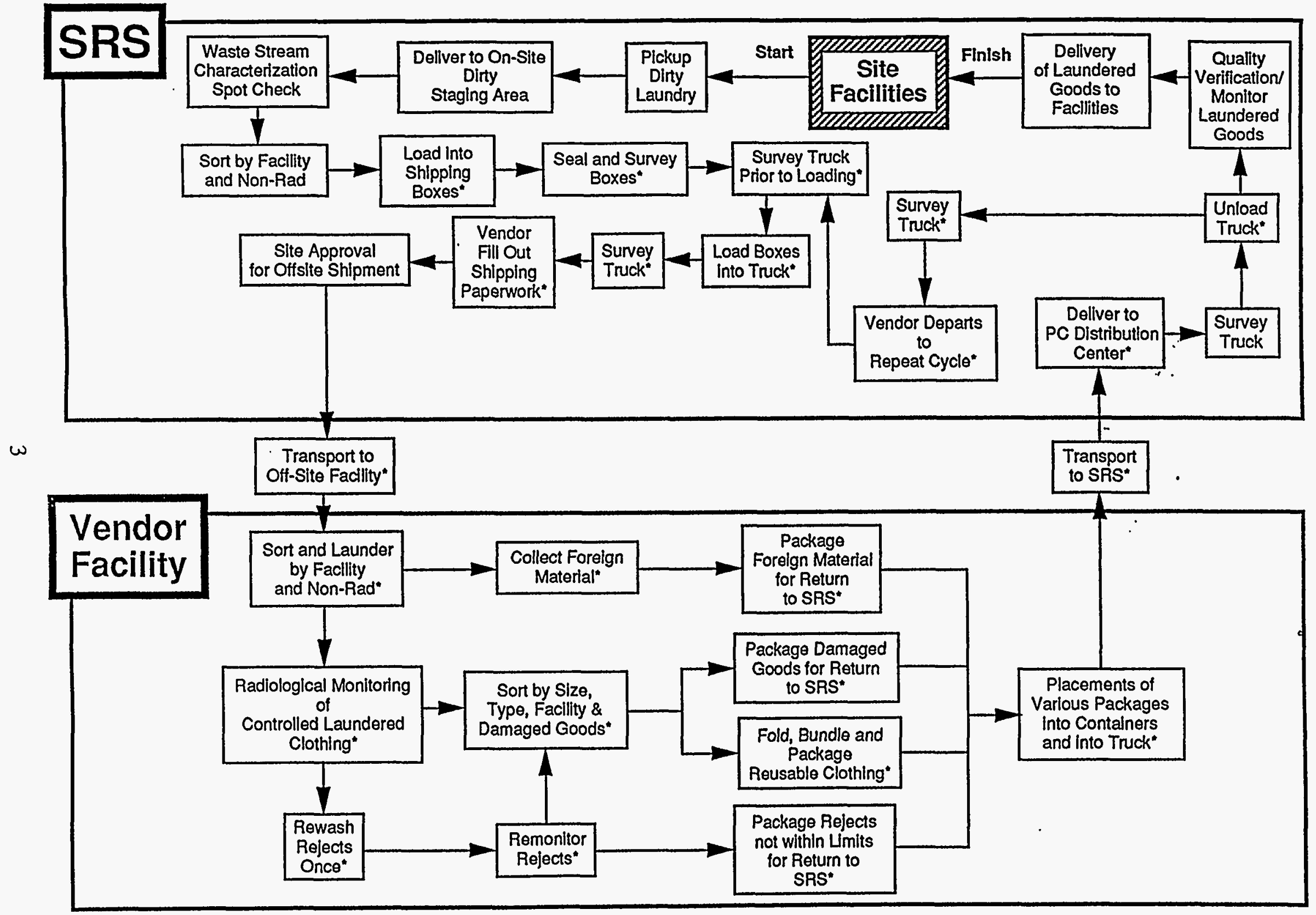

Figure 2-1. Flowchart for the commercial cleaning of protective clothing from Savannah River Site, South Carolina. 


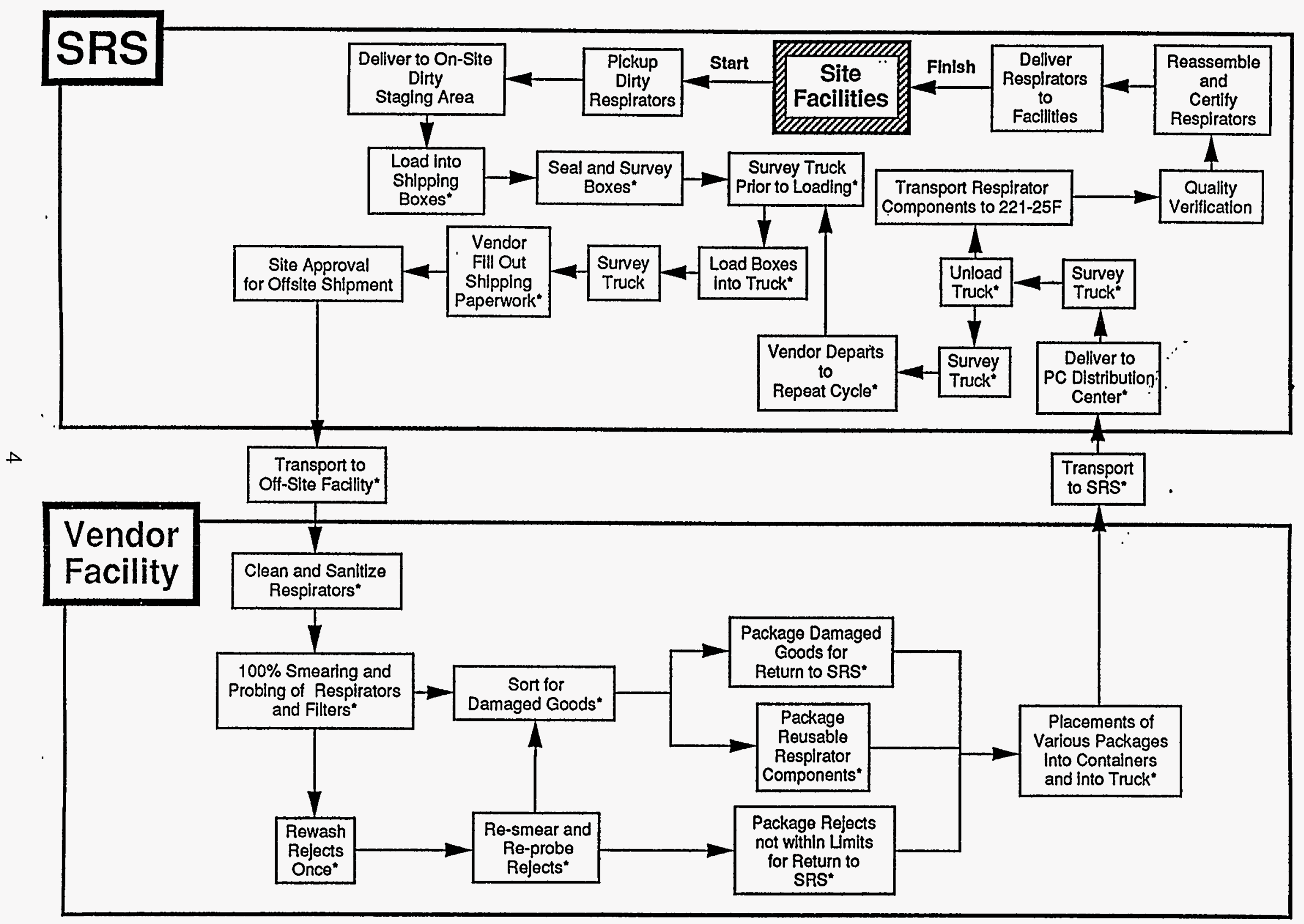

Figure 2-2. Flowchart for the commercial cleaning of respirators from Savannah River Site, South Carolina. 


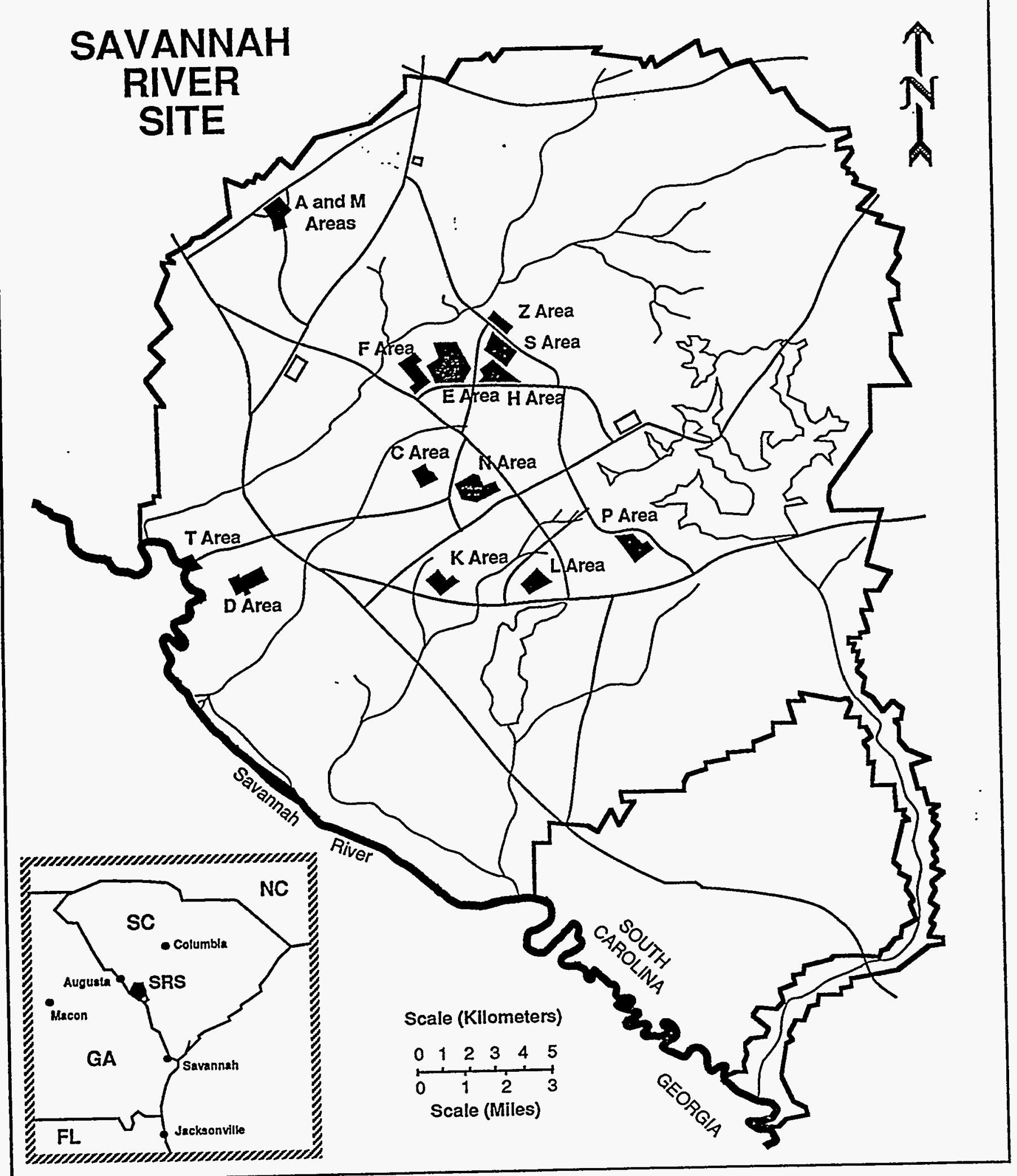

Figure 2-3. Map illustrating the general locations of the various site areas participating in the commercial laundry services at the Savannah River Site, South Carolina. 
Table 2-1. Listing of maximum contamination limits for transportation and reuse of laundered goods at the Savannah River Site.

\begin{tabular}{|c|c|c|c|}
\hline \multirow{2}{*}{ Criteria } & \multicolumn{2}{|c|}{ Contamination Source } & \multirow{2}{*}{ Reference } \\
\hline & $\begin{array}{c}\text { Beta-gamma } \\
\text { (in dpm/100 } \mathrm{cm}^{2} \text { )ab }\end{array}$ & $\begin{array}{c}\text { Alpha } \\
\text { (in dpm/100 } \mathrm{cm}^{2} \text { ) }\end{array}$ & \\
\hline $\begin{array}{l}\text { Individual Articles of } \\
\text { Clothing }\end{array}$ & $<1,000,000$ & $<20,000$ & 49 CFR 173.425 \\
\hline $\begin{array}{c}\text { External } \\
\text { Contamination of } \\
\text { Container } \\
\text { (i.e., Box or Bag) }\end{array}$ & $<200$ & $<20$ & 5Q Manual Article 423 \\
\hline $\begin{array}{l}\text { Individual Articles of } \\
\text { Clothing/Reuse }\end{array}$ & $<10,000$ & $<1,000$ & 5Q Manual Ch. 4, Part 6 \\
\hline
\end{tabular}

a dpm - disintegrations per minute

$\mathrm{b}$ square centimeters can be converted to square inches by multiplying the square centimeters by 0.06 
The vendor would be required to adhere to all SRS safety rules and regulations while operating on site. Each vendor employee who works on the SRS premises would have to complete and submit a radiation exposure history, and obtain all required Fastscan and bioassay examinations. DOE would provide information to the vendor on the potential levels and types of radiation/contamination for the containerized protective clothing as well as for individual items. The vendor would be responsible for choosing the type(s) of radiation detection equipment to be worn by their employees. The vendor would further be required to provide a specific company safety plan for all commercial activities to be conducted on SRS. If the same vehicle is proposed for use in transporting both dirty and clean clothing, the vendor would be required to provide a detailed description of the process to survey and clean the vehicle to assure no cross contamination. The practice on site has been to clean removable contamination with atomic wipes, while fixed contamination is ground out of metal and sanded off of wooden surfaces. In either case, the resultant waste material is in solid form and is disposed of with other waste from the laundry process. No liquid waste would be created during such decontamination processes. The vendor would also furnish SRS with all Material Safety Data Sheets for all chemicals used by the vendor in its laundering services.

Under the terms of the contract, the vendor would be responsible for identifying and complying with all applicable laws and regulations governing the operation of the offsite facility and shipment of the laundry to and from SRS. This would include having the capabilities to obtain all applicable state and Federal licences and permits necessary to provide and operate a nuclear laundry facility at the vendor's location. The vendor would further be required to have the capabilities to obtain the necessary licences and permits to handle and dispose of various radioactive or hazardous waste materials which may be potentially generated at the offsite facility.

The distribution process on site after laundering would entail random monitoring to assure compliance and delivery of the cleaned laundry. In addition, to ensure that laundered goods returned to the site are within the appropriate contamination limits for reuse (Table 21), site HP would monitor clothing and respirators upon returning to the site and prior to distribution.

\subsection{Alternatives to the Proposed Action}

In accordance with NEPA regulations, DOE examined the following alternatives to the proposed action:

- No action, continue to use the existing laundry facility at SRS

- Expand and refurbish the existing laundry facility at SRS

- Construct a new replacement laundry facility at SRS

\subsubsection{No Action, Continue to Use the Existing Laundry Facility at SRS}

One alternative to the proposed action is to take no action. This would consist of SRS continuing to use the existing laundry facilities in F Area for cleaning of controlled and routine laundry. The impacts associated with the proposed action would not occur. The state of the existing systems would continue to require extensive maintenance under an ongoing workload. The facility is located in an area that may be subject to increased security measures in the near future. The physical plant layout of the existing laundry is not efficient or responsive to good practice for Radiologically Controlled Area (RCA) management. In addition, the aforementioned issue concerning the diversion of the 
wastewater discharge to the ETF in $\mathrm{H}$ Area resulting in the effluent not meeting requirements under the Clean Water Act would not be resolved.

\subsubsection{Expand and Refurbish the Existing Laundry Facility at SRS}

A second alternative would be to expand and refurbish the existing laundry in F Area. This facility lacks adequate space for proper expansion and refurbishment. The existing laundry is located in a security restricted area and an RCA (i.e., an area to which access is controlled in order to protect personnel from exposure to radiation and radioactive materials). In addition to these upgrading activities, a new waste water treatment system would have to be constructed to support an expanded and refurbished laundry. Upgrade costs are estimated to be at least twice as high as compared to a similar facility without the aforementioned limitations.

\subsubsection{Construct a New Replacement Laundry Facility at SRS}

Another alternative to the proposed action would be to construct a new replacement laundry and waste water treatment system and related support equipment at an alternate SRS location to replace the existing laundry facility in F Area. This alternative would require the construction and operation/maintenance of a new $2,973 \mathrm{~m}^{2}\left(32,000 \mathrm{ft}^{2}\right)$ onsite facility for the cleaning of both controlled and routine laundry. The estimated cost of the construction and operation of a replacement laundry facility for SRS is approximately the same as the previous alternative.

\subsection{ENVIRONMENTAL CONSEQUENCES OF THE PROPOSED ACTION AND ALTERNATIVES}

The SRS occupies an area of approximately $800 \mathrm{~km}^{2}\left(300 \mathrm{mi}^{2}\right)$ in southwestern South Carolina (Figure 2-3). The site borders the Savannah River for about $27 \mathrm{~km}$ (17 mi) near Augusta, Georgia, and Aiken and Barnwell, South Carolina. SRS contains five nuclear production reactor areas, two chemical separations areas, waste processing, storage and disposal facilities, and various supporting facilities. The different facilities generating laundry to be cleaned by the vendor services are located at various locations around the site. The Final Environmental Impact Statement for the Continued Operation of K-, L-, and PReactors (DOE, 1990) and the most recent socioeconomic survey of the six-county SRS area of influence (NUS, 1992) contain additional information on SRS areas and facilities, and the areas surrounding the SRS.

\subsection{Vendor Facility Operation}

The specific details of the operation of the vendor facility are presently unknown since the contract has not been awarded. It can be assumed that the operation of that facility would be similar to the existing site laundry facility in F Area, which is classified as a low hazard facility (WSRC, 1993c, 1993e). As per DOE Order 5481.1B, a low hazard classification is used to define facilities which, in the event of an unmitigated release of the total radiological inventory contained in that facility, would present only minor onsite and negligible offsite impacts to either people or the environment. The average worker dose at the existing SRS laundry is 2.5 mrem/year. This represents less than one percent of the average annual dose that a person residing in the area around the SRS receives from natural sources of radiation (WSRC, 1993d). The maximum reasonable accident analyzed for the laundry was a fire resulting in all of the controlled laundry (i.e., protective clothing and respirators) present in the facility being completely burned and the total inventory of 
radionuclides being released. The radionuclide dose calculations were based on airborne radioactivity without any credit for facility process engineering features or administrative controls to mitigate the consequences of the subject release. The computed maximum radiological dose for an onsite individual is $5.47 \times 10^{-2} \mathrm{rem}$ and for an offsite individual is $1.03 \times 10^{-4} \mathrm{rem}$ (WSRC, 1993e). Based on the International Commission on Radiological Protection and United National Scientific Committee estimate of $1 \times 10^{-4}$ excess cancer deaths per 1 rem of exposure, operation of a facility similar to the existing site laundry would not result in any fatalities associated with either exposure to or releases of radioactive materials. Based on the chemical inventory for the existing laundry, no hazards would be expected by the operation of a similar facility (WSRC, 1993e). The amount of fissile material present in the existing laundry at any one time is well below the minimum critical mass for plutonium. Therefore, a criticality is not a credible event (WSRC, 1993c). Effluent discharges from the vendor facility would be assumed to be similar to those from the existing SRS laundry facility. Waste water effluent from the operations in Building 723-F have been documented as being low in both chemical and radiological contamination. Laboratory analyses of waste water samples have provided results which indicate that the effluent is not hazardous waste, as defined in 40 CFR Part 261. Effluent from the current SRS laundry operations is discharged through a permitted National Pollutants Discharge Elimination System (NPDES) outfall.

\subsection{SRS Facility Operations}

The only onsite facility associated with the proposed action would be the existing laundry facility being converted into the combined dirty staging area/PC distribution center facility. The volume of laundry at the dirty staging area (i.e., approximately 600 bags/day) would be less than that for the existing laundry operation (i.e., approximately 1,200-2,000 bags/day). Therefore, any potential impacts at the dirty staging area would also be less than for the existing site laundry operations. The onsite waste disposal of the discardable material generated by the laundering operations would be expected to be approximately the same as that experienced at present.

The other onsite operational impacts from the proposed action would be the termination of the laundering operations in Building $723-\mathrm{F}$. This would reduce the domestic water withdrawals from $F$ Area wells by approximately 151,400 liters $(40,000$ gallons) per day, and the potable water withdrawals by slightly less than 3785 liters (1000 gallons) per day. Waste water discharges would be decreased by approximately 151,400 liters $(40,000$ gallons) per day. Discontinued use of the subcontractor services operating the existing facility would result in the employment termination of approximately 46 people.

\subsection{Transportation Impacts}

\subsubsection{Analyzed Scenario}

Currently, contaminated laundry is bagged and collected from 78 locations around SRS (WSRC, 1993a) and brought to the site laundry facility in F Area for processing. The laundry bag external contamination is limited to very low values. Under the proposed action, the laundry would continue to be bagged, collected, and brought to the F Area facility.

Under the proposed action, the laundry bags would be placed into metal boxes at the laundry facility for shipment. The typical capacity of the laundry boxes is 363 to 454 kilograms ( 800 to 1000 pounds) of laundry. As often as is necessary, the laundry boxes would be loaded onto a tractor-trailer truck for shipment to the selected vendor's laundry 
facility. A full load would contain twenty-two laundry boxes. Although the vendor has not been selected, three southeastern cities were selected for analysis as representative vendor locations. Two of these cities, Columbia, South Carolina and Macon, Georgia, are known to have vendors in the contaminated laundry business. The third city, Jacksonville, Florida, was selected because of its size and potential to have contaminated laundry facilities to support naval facilities.

Although respirators could be part of the truck load and radioactivity contamination per unit volume is the same as laundry, the analyzed scenario was for shipping contaminated laundry. Any space potentially filled by respirators is assumed to be filled by contaminated laundry. After laundering, the clean laundry would be returned to the site laundry facility for subsequent distribution to the individual facilities. Based on averages over the last three years, about 126,984 kilograms (280,000 pounds) of contaminated laundry and 8300 contaminated respirators are used per month (WSRC, 1993b). This would result in about 20 shipments per month if unchanged.

Because the laundry collection process under the proposed action and alternatives is identical to that under current operation (i.e., no action alternative), an analysis of the transportation impacts of laundry collection is not performed. Consequences of laundry collection would be less than that for an offsite shipment because the volume of contaminated laundry involved in individual onsite shipments is less than that for the offsite (outbound) shipments. Because both the volume and associated levels of contamination would be less than the outbound trip of contaminated laundry, a radiological impacts analysis was not performed for the onsite collection because the consequences would be bounded by the analysis for the outbound scenario.

A radiological impacts analysis was not performed for the return trip of clean laundry since the consequences would be bounded by the outbound trip of contaminated laundry. Therefore, the radiological transportation analysis is limited to the outbound, offsite shipment of contaminated laundry. Nonradiological consequences (e.g., traffic accident fatality) are determined for both the outbound and return trips.

\subsubsection{Assumptions}

The amount of radioactivity that would be expected in a shipment of contaminated laundry was determined from laundry liquid effluent release limits (WSRC, 1993c), liquid effluent analysis results (WSRC, 1993d), truck capacity (Crusselle, 1993), and laundry operating data (WSRC, 1993c). The estimated radioactivity in a 9,977 kilogram (22,000-pound) truck load is approximately $4.6 \times 10^{-4}$ curies for beta/gamma emitters and $1.4 \times 10^{-4}$ curies for alpha emitters.

To determine incident-free consequences, the total radioactivity was conservatively assumed to result from radiocesium, which provides the greatest external hazard of all the potential radionuclides in the laundry. The external dose rate one meter from the truck, without considering the shielding of the steel laundry containers and the trailer sides, was determined to be about $1.6 \times 10^{-2}$ mrem per hour. This very low dose rate is consistent with SRS measurements indicating that there is no detectable dose rate on contact with the laundry bags (using conventional survey instruments). Dose rates to receptors along the transportation route and to the driver of the truck would be indistinguishable from background; therefore, no doses were calculated for these receptors.

For accident considerations, the calculated radioactivity was assigned to be radiostrontium for the beta-gamma emissions and plutonium for the alpha emissions. The selection of 
these two radionuclides is consistent with the analysis in the Hazard Assessment Document for the laundry facility (WSRC, 1993c). Routes and demographic information for shipments to selected cities were determined using the HGHWAY computer code (Johnson, 1993). Release of radioactive particles to the atmosphere were assumed to occur only in the case of accidents with fire. Releases resulting from non-fire accidents were determined to be inconsequential based on historical airborne radioactivity concentrations in the laundry building. The analysis was performed under the following assumptions: (1) all of the contaminated clothing is completely incinerated; and (2) one percent of the radioactivity dispersed in the atmosphere is in respirable form (i.e., an average median aerodynamic diameter of less than 10 microns) (WSRC, 1993c). The computer code RADTRAN was selected for the analysis (Neuhauser, 1992).

\subsubsection{Consequences}

The radiological consequences of a transportation accident depend upon the severity of the accident and the population density at the location of the accident. Urban locations have higher accident probabilities and greater consequences for a given accident severity but generally have lower accident severities because of lower speeds. Rural locations have fewer accidents per mile and lesser consequences; however, the accident severities are generally greater. The RADTRAN results are presented in Table 3-1 for accidents in rural, suburban, and urban locations for transportation to each of the selected cities. The values are for a single shipment.

Currently, there are sufficient laundry and respirators to require approximately 20 offsite shipments (allowing for some inefficiencies) per month. The probabilities and risk values provided in Table 3-1 should be multiplied by the number of truck loads to arrive at the total probabilities and risk. The consequences would remain unchanged.

RADTRAN also provided results of an accident in the F Area near the laundry building. The F Area population density was calculated assuming all shifts were on duty simultaneously. No accident probability was determined because F Area is unlike any transportation environment previously analyzed. (Accident probabilities have been characterized for urban, suburban, and rural environments. F Area resembles an urban manufacturing environment, but the traffic density is extremely low.) Regardless of destination, should an accident involving the complete combustion of the laundry occur in $F$ Area, the calculated collective dose to F Area workers would be $2.4 \times 10^{-1}$ person-rem.

The International Commission on Radiological Protection has determined the number of latent cancer fatalities per person-rem of collective dose (ICRP, 1991). For workers, this value is $4 \times 10^{-4}$ latent cancer fatalities per person-rem; for the public, this value is $5 \times 10^{-4}$ latent cancer fatalities per person-rem. These values can be used to estimate the human health effects from the transportation accidents described.

The maximum calculated public dose would occur as a result of an accident with fire along the Jacksonville route (Table 3-1). The potential latent cancer fatalities for this accident would be $1.5 \times 10^{-1}$ times $5.0 \times 10^{-4}$ or $7.5 \times 10^{-5}$. For the accident in $\mathrm{F}$ Area, the potential latent cancer fatalities would be $2.4 \times 10^{-1}$ times $4.0 \times 10^{-4}$ or $9.6 \times 10^{-5}$. To place these values into perspective, additional calculations indicate that SRS would have to ship laundry to Jacksonville for about $\mathbf{4 0}$ million years to produce one latent cancer fatality. 
Table 3-1. Listing of offsite radiological transportation accident consequences and probabilities associated with the proposed action.

\begin{tabular}{|c|c|c|c|c|}
\hline Destination & $\begin{array}{l}\text { Accident } \\
\text { Location }\end{array}$ & $\begin{array}{l}\text { Collective Dose } \\
\text { (person-rem) }\end{array}$ & $\begin{array}{l}\text { Accident } \\
\text { Probability }\end{array}$ & $\begin{array}{l}\text { Risk } \\
\text { (Collective Dose } \\
\text { x Probablity) }\end{array}$ \\
\hline Columbia, SC & $\begin{array}{l}\text { Rural } \\
\text { Suburban } \\
\text { Urban } \\
\text { Total }\end{array}$ & $\begin{array}{c}1.5 \times 10^{-3} \\
3.0 \times 10^{-2} \\
1.2 \times 10^{-1} \\
\text { not additive }\end{array}$ & $\begin{array}{l}2.2 \times 10^{-7} \\
1.8 \times 10^{-6} \\
1.5 \times 10^{-7} \\
2.2 \times 10^{-6}\end{array}$ & $\begin{array}{l}3.3 \times 10^{-10} \\
5.4 \times 10^{-8} \\
1.8 \times 10^{-8} \\
7.2 \times 10^{-8}\end{array}$ \\
\hline Macon, GA & $\begin{array}{c}\text { Rural } \\
\text { Suburban } \\
\text { Urban } \\
\text { Total }\end{array}$ & $\begin{array}{c}1.4 \times 10^{-3} \\
3.4 \times 10^{-2} \\
1.1 \times 10^{-1} \\
\text { not additive }\end{array}$ & $\begin{array}{l}4.0 \times 10^{-7} \\
3.2 \times 10^{-6} \\
5.9 \times 10^{-7} \\
4.2 \times 10^{-6}\end{array}$ & $\begin{array}{l}5.6 \times 10^{-10} \\
1.1 \times 10^{-7} \\
6.5 \times 10^{-8} \\
1.8 \times 10^{-7}\end{array}$ \\
\hline $\begin{array}{c}\text { Jacksonville, } \\
\text { FL }\end{array}$ & $\begin{array}{l}\text { Rural } \\
\text { Suburban } \\
\text { Urban } \\
\text { Total }\end{array}$ & $\begin{array}{c}1.0 \times 10^{-3} \\
2.4 \times 10^{-2} \\
1.5 \times 10^{-1} \\
\text { not additive }\end{array}$ & $\begin{array}{l}7.0 \times 10^{-7} \\
2.8 \times 10^{-6} \\
1.3 \times 10^{-6} \\
4.8 \times 10^{-6}\end{array}$ & $\begin{array}{l}7.0 \times 10^{-10} \\
6.7 \times 10^{-8} \\
2.0 \times 10^{-7} \\
2.7 \times 10^{-7}\end{array}$ \\
\hline
\end{tabular}


The primary nonradiological transportation consequence is a traffic accident fatality. Table 3-2 provides the expected accident frequencies and numbers of accidents with fatalities. The accident frequencies (accidents/kilometer) are provided by RADTRAN. The distances are provided by HIGHWAY. The percent of tractor-trailer accidents resulting in fatalities, 7.5 percent, is from the U.S. Department of Transportation (DOT, 1989).

The values in Table 3-2 are for a single round trip shipment. The numbers of accidents and numbers of accidents with fatalities should be multiplied by the expected number of shipments. The numbers of shipments should be determined including both radiological and nonradiological laundry, which according to current usage could amount to about 25 shipments per month. Further calculations indicate SRS would have to ship laundry to Jacksonville for about 160 years before an accident resulting in a fatality would be expected to occur.

\subsection{Environmental Consequences of the Alternatives}

The environmental consequences associated with the alternatives are described in the following paragraph. The no action alternative would result in a continuation of the environmental consequences (e.g., effluent discharges not meeting current regulatory requirements under Section 401 of the Clean Water Act, withdrawal of groundwater for domestic and potable use) which are ongoing at the existing site laundry. In addition to the increased costs, the alternative to expand and refurbish the existing laundry would result in the continued impacts resulting from the current laundry operations. The construction of an effluent treatment system would require some land use; however, this would be in an already developed area. The impacts associated with that action would be negligible. The alternative for a new replacement laundry at SRS would result in impacts associated with construction and operation of such a facility. This alternative would require clearing of the project site. The proposed development site is currently a $0.02 \mathrm{~km}^{2}$ (5 acre) planted pine stand located adjacent to F-Area. No environmentally sensitive areas or natural resources such as historical or archaeological sites, endangered species or their habitats, or wetlands are present at the subject site (SRARP, 1989; Rogers, 1990; SRFS, 1992; Wike et al., 1993), and therefore would not be affected. The operation of a replacement laundry facility would similar that of the previous alternative. Based on analyses conducted on the existing laundry facility, no latent cancer fatalities would be expected as a result of either normal operational or accidental releases associated with any of these alternatives.

\subsection{Other Impacts}

\subsubsection{Safeguards and Security}

All additional safeguard and security measures required by the applicable DOE orders would be provided for the onsite facilities and transportation activities.

\subsubsection{Emergency Planning}

DOE has developed a series of emergency response plans with the cooperation of state and county agencies to comply with DOE Order 5500 series emergency preparedness orders to respond to any onsite incidents at SRS.

\subsection{Cumulative Impacts}

The principal cumulative impacts from the proposed action would be those effects associated with the closure of the existing site laundry facility in F Area. The site usage of 
Table 3-2. Nonradiological accident consequences associated with the proposed action.

\begin{tabular}{ccccc}
\hline Destination & $\begin{array}{c}\text { Distance } \\
\text { (in km) }\end{array}$ & $\begin{array}{c}\text { Accident Rate } \\
\text { (weighted by } \\
\text { distance in each } \\
\text { population density) }\end{array}$ & $\begin{array}{c}\text { Number of } \\
\text { Accidents }\end{array}$ & $\begin{array}{c}\text { Number of } \\
\text { Accidents } \\
\text { Resulting in } \\
\text { Fatalities }\end{array}$ \\
\hline Columbia, SC & 274 & $1.01 \times 10^{-6}$ & $2.77 \times 10^{-4}$ & $2.07 \times 10^{-5}$ \\
Macon, GA & 500 & $1.05 \times 10^{-6}$ & $5.25 \times 10^{-4}$ & $3.95 \times 10^{-5}$ \\
Jacksonville, FL & 763 & $7.75 \times 10^{-7}$ & $5.91 \times 10^{-4}$ & $4.43 \times 10^{-5}$ \\
\hline
\end{tabular}

a kilometers can be converted to miles by multiplying the kilometers by 0.62 
domestic and potable water would be decreased by less than one percent. The discharge of treated waste water to the receiving stream would also be decreased by less than one percent. The decrease in the site workforce would be less than one percent. No latent cancer fatalities would be expected to result from the proposed action.

\subsection{REgULATORY AND PERMITTING PROVISIONS CONSIDERED}

DOE policy is to carry out its operations in compliance with all applicable federal, state, and local laws and regulations, as well as all DOE orders. This section provides a discussion of the major regulatory permit programs that might be applicable to the proposed action.

\subsection{National Environmental Policy Act of 1969, as amended (42 USC 4321 et seq.)}

This EA has been prepared in compliance with the NEPA of 1969, as amended, and the requirements of the Council of Environmental Quality Regulations for Implementing NEPA (40 CFR Parts 1500-1508), and DOE Regulations (10 CFR Part 1021), and DOE Order 5440.1E. NEPA, as amended, requires "all agencies of the Federal Government" to prepare a detailed statement on the environmental effects of proposed "major Federal actions significantly affecting the quality of the human environment." This EA has been written to comply with NEPA and assess the environmental effects associated with the offsite commercial cleaning of controlled and routine laundry from the SRS.

\subsection{Air Emission Regulations}

The vendor awarded the contract for the offsite commercial laundry facility must comply with radionuclide releases requirements under the Clean Air Act and any applicable state regulations (e.g., SCDHEC Air Pollution Control Permit levels).

\subsection{Liquid Discharge Regulations}

Wastewater discharges from the offsite commercial facility must be permitted either under Section 401 of the Clean Water Act or applicable state regulations (e.g., SCDHEC NPDES regulations).

\subsection{AGENCIES AND PERSONS CONSULTED}

Personnel from Interstate Nuclear Services, Inc. were consulted during the preparation of this EA. 


\subsection{REFERENCES}

Crusselle, V. (Interstate Nuclear Services, Inc.). 1993. Personal communication with S. J. Connor (Halliburton NUS Corporation).

DOE (Department of Energy). 1990. Final Environmental Impact Statement. Continued Operation of K-, L-, and P-Reactors, Savannah River Site. DOE/EIS-0147, Savannah River Operations Office, Aiken, SC.

DOE (Department of Energy). 1991. Nuclear Weapons Complex Reconfiguration Study. DOE Defense Programs 0083, U. S. Department of Energy, Washington, DC.

DOE (Department of Energy). 1991a. Intent to Prepare Programmatic Environmental Impact Statement for Reconfiguration of the Nuclear Weapons Complex. Federal Register, 56 FR 5590-5596, Washington, DC.

DOT (Department of Transportation). 1989. Accidents Reported by Motor Carriers of Property 1989. FHWA/MC-92/018. U. S. Department of Transportation, Federal Highway Administration, Office of Motor Carriers, Washington, DC.

ICRP (International Commission on Radiological Protection). 1991. 1990 Recommendations of the International Commission on Radiological Protection. ICRP Publication 60, Pergamon Press, New York.

Johnson, P.E., et al. 1993. HIGHWAY 3.1 - An Enhanced Highway Routing Model: Program Description, Methodology, and Revised User's Manual. ORNL/TM-12124, Oak Ridge National Laboratory, Oak Ridge, Tennessee.

Neuhauser, K. S. and F. L. Kanipe. 1992. RADTRAN 4: Volume 3 User Guide. SAND89-2370; TTC-0943; UC-722. Sandia National Laboratories, Albuquerque, New Mexico.

NUS (Halliburton NUS Environmental Corporation). 1992. Socioeconomic Characteristics of Selected Counties and Communities Adjacent to the Savannah River Site. July 1992. Halliburton NUS Corporation, Aiken, South Carolina.

Rogers, V. A. 1990. Soil Survey of Savannah River Plant Area, Parts of Aiken, Barnwell, and Allendale Counties, South Carolina. U. S. Department of Agriculture, Soil Conservation Service, Aiken, South Carolina.

SRARP (Savannah River Archaeological Research Program). 1989. Archaeological Resource Management Plan of the Savannah River Archaeological Research Program. Savannah River Archaeological Research Program, South Carolina Institute of Archaeology and Anthropology, University of South Carolina, Aiken, South Carolina.

SRFS (Savannah River Forest Station). 1992. Savannah River Site Proposed, Threatened, Endangered, and Sensitive Plants and Animals. Savannah River Forest Station, New Ellenton, South Carolina. 
Wike, L. D., R. W. Shipley, A. L. Bryan, Jr., J. A. Bowers, C. L. Cummins, B. R. del Carmen, G. P. Friday, J. E. Irwin, J. J. Mayer, E. A. Nelson, M. H. Paller, V. A. Rogers, W. L. Specht, and E. W. Wilde. 1993. SRS Ecology: Environmental Information Document. WSRC-TR-93-496, Westinghouse Savannah River Company, Savannah River Site, Aiken, South Carolina.

WSRC (Westinghouse Savannah River Company). 1993a. General Services Laundry Operations. Manual D1-5-3. Savannah River Site, Aiken, South Carolina.

WSRC (Westinghouse Savannah River Company). 1993b. "Scope of Work for the Procurement of Commercial Laundry Services." Interoffice Memorandum C. H. Ashford and J. P. Bernard to J. Bernard, et al., SSD, FSD-93-12339, Savannah River Site, Aiken, South Carolina.

WSRC (Westinghouse Savannah River Company). 1993c. Hazards Assessment Document, 723-F Laundry Facility. WSRC-TR-93-310, Savannah River Site, Aiken, South Carolina.

WSRC (Westinghouse Savannah River Company). 1993d. Savannah River Site Environmental Data for 1992. WSRC-TR-93-077, Savannah River Site, Aiken, South Carolina.

WSRC (Westinghouse Savannah River Company). 1993e. Calc-Note: Hazards Assessment for the 723-F Laundry Facility. SRT-WAG-93-9009, Savannah River Site, Aiken, South Carolina. 